\title{
From Chronology to Confessional: New Zealand Sporting Biographies in Transition
}

\author{
GEOFF WATSON
}

\begin{abstract}
Formerly rather uniform in pattern, sporting biographies have evolved significantly since the 1970s, becoming much more open in their criticism of teammates and administrators as well as being more revealing of their subject's private lives. This article identifies three transitional phases in the genre; a chronological era, extending from the early twentieth century until the 1960s; an indirectly confessional phase between the 1970s and mid 1980s and an openly confessional phase from the mid-1980s. Despite these changes, sporting biographies continue to reinforce the dominant narratives around sport in New Zealand.
\end{abstract}

New Zealand sporting biographies have a mixed reputation in literary and scholarly circles. Often denigrated for their allegedly formulaic style, they have also been criticised for their lack of insight into New Zealand society. ${ }^{1}$ Representative of this critique is Lloyd Jones, who wrote in 1999, "sport hardly earns a mention in our wider literature, and ... the rest of society is rarely, if ever, admitted to our sports literature."2 This article examines this perspective, arguing that sporting biographies afford a valuable insight into New Zealand's changing selfimage and values. Moreover, it will be argued that the nature of sporting biographies themselves has changed significantly since the 1980s and that they have become much more open in their discussion of teammates and the personal lives of their subjects. Whatever one's perspective on the literary merits of sporting biographies, their popular appeal is undeniable. Whereas the print run of most scholarly texts in New Zealand is at best a few thousand, sporting biographies consistently sell in the tens of thousands. Alex Veysey's Colin Meads: All Black, published in 1974 sold 61,000 copies while Richie McCaw's biography The Open Side, published in 2012, had sold 120,000 copies by the end of that year. ${ }^{3}$ The popularity of sporting biographies makes them an important site for scholarly study because the perspectives they provide on social issues reach a far wider audience than academic texts. For the purposes of this article, the definition of sporting biographies encompasses works written about a particular sportsperson and what I term "Tour Books." These were books written primarily by journalists about tours to New Zealand by visiting sports teams or books written about New Zealand teams who toured overseas and were a staple of the New Zealand sporting public's literary diet. ${ }^{4}$ Although ostensibly about sporting events, many of these books included lengthy pen portraits of the players.

The article commences with a brief overview of the development of sporting biographies before charting three transitional phases in their development. It then discusses three major changes in their subject matter: sporting contacts with South Africa, the emergence of the coach as a biographical subject and the treatment of women in sporting biographies. As a generalization, it can be argued that until the 1970s, sporting biographies were essentially chronological in nature, focusing on the sporting career of their subjects. During the 1970s and 1980s, an indirectly confessional element emerged, with some works critiquing administrators and writing about off-field incidents in general terms. From the mid-1980s, they became more openly confessional, naming the names of those perceived to have undermined team harmony and being more open about their subjects' personal lives. The scope of sporting biographies also widened. Whereas the early biographies principally focused on the most 
distinguished rugby and cricket players, more recent biographies have focused on subjects who have not necessarily had lengthy international careers but attracted publicity because they were either involved in controversial incidents or are seen as "colourful" characters. ${ }^{5}$

\section{Development of Sporting Biographies.}

Although there was extensive reporting on sport in New Zealand, biographies of sporting personalities and indeed works on the history of sport in New Zealand were infrequent before 1945. ${ }^{6}$ Despite the status of rugby union (hereafter rugby) as the national game of New Zealand, it was not until 1948, approximately 80 years after the first recorded game of rugby in New Zealand in 1870, that Arthur Swan's History of New Zealand Rugby Football was published. ${ }^{7}$ Although not strictly speaking an autobiography, Tom Ellison's The Art of Rugby Football, which was published in 1902, is arguably the first canonical text in New Zealand sporting literature. ${ }^{8}$ Ellison, of Ngai Tahu ancestry was a member of the 1888-1889 New Zealand Native Team, which was the first New Zealand rugby team to tour Britain, and captained the first New Zealand team selected under the auspices of the New Zealand Rugby Football Union (NZRFU) in 1893. The significance of his book lies in its nationalist interpretation of rugby in New Zealand. Whereas most New Zealand sports followed the rules and tactics of games as they were played in Britain, Ellison outlined distinct elements of New Zealand rugby, including the 2-3-2 scrum formation and the Wing Forward position. Moreover, he emphasized the primacy of New Zealanders in developing rugby in their own country, arguing that New Zealand had learned little from British teams and, in an often quoted phrase, praised rugby as a "soldier-making game." number of players and officials wrote about tours in which they had been involved, such as manager Thomas Eyton's account of the 1888-89 Native Team, George Dixon's account of the 1905 All Black Tour and Mark Nicholls' book on the 1928 All Black tour of South Africa. The focus of these books, however, was on the sporting aspects of tours rather than the players themselves. ${ }^{10}$ Such was the interest in rugby in New Zealand that books written by overseas scribes such as R. A. Barr, who accompanied the Anglo-Welsh team to New Zealand in 1908, and Denis Lalanne, who accompanied the French team to New Zealand in 1961, have been reprinted in New Zealand. A detailed analysis of these is beyond the scope of this article, but collectively such works provided external validation of New Zealand's prowess at rugby. ${ }^{11}$

New Zealand sporting biographies in their modern form emerged from the late 1940s. ${ }^{12}$ In 1954 Terry McLean and Dick Brittenden, two writers who, along with Garth Gilmour, might be regarded as leading figures in popularizing sporting biographies, published their first books. Like most writers of sporting biographies until the 1980s they came from a background in journalism. Their credibility as biographers was enhanced by their knowledge of sport and also because they were to some degree "insiders" who accompanied their subjects on tour and had much closer access to them than most present day media. ${ }^{13}$ Brittenden's Silver Fern on the Veld, on the New Zealand Cricket team's tour of South Africa in 1953-54, demonstrated the capacity of New Zealand sports writers to produce literature that transcended mere reportage, especially his account of Bert Sutcliffe and Bob Blair's courageous last wicket stand in the second test. ${ }^{14}$ Terry McLean's first book, Bob Stuart's All Blacks, was an account of the 1953-54 tour of the United Kingdom and France, and was published in 1954. His first biography, The Bob Scott Story, appeared in $1956 .{ }^{15}$ McLean, who would write more than thirty books during his career, earned a reputation as the doyen of New Zealand sports journalism. ${ }^{16}$ His writing on sport was very much shaped by his service during the Second World War, extolling the virtues of discipline and pride in performance, and he took a keen interest in how people performed under pressure. ${ }^{17}$ As his biographers suggested, he "counted himself not so much a sports writer as an observer of the human condition."18 Garth Gilmour's 
writing focused on athletics. He developed a close association with Arthur Lydiard, with whom he co-authored several books on running, and the athletes Lydiard coached, including 1960 Olympic gold medalists Murray Halberg and Peter Snell, whose victories symbolized the ability of amateur New Zealand athletes to triumph on the world stage. ${ }^{19}$

The standard sporting biography comprised a brief overview of the subject's childhood, which charted their rise to sporting prominence, before discussing their playing career and, often concluded with a "dream team" in which the subject selected either their ideal team, or a best all-time New Zealand team and a team comprising the best opponents they had played against. Alex Veysey's best-selling Colin Meads: All Black exemplifies this format. The vast majority of sporting biographies are "ghost-written," that is, they are related by their subject to a third party and presented in the voice of their subject. From a marketing perspective, books with the imprimatur of being the subject's "own words" on the subject are more desirable because they are seen as being more "authentic" and more likely to contain personal revelations than unauthorized biographies, which are relatively infrequent. ${ }^{20}$ It is rare, though not unusual, for a sports-person in New Zealand to write their own biography, Chris Laidlaw, Andy Haden, David Kirk and Martin Crowe being among those to do so. Until the openly confessional era, such works were much more candid than their contemporaries. Sporting biographies were, and mostly still are, written by men about male subjects and aimed primarily at a male audience, their release often being timed for Father's Day and the Christmas and New Year period. ${ }^{21}$ Because they are often purchased as presents it is difficult to know the extent to which they are read by their recipients, but at the very least it can be said that they are a popular medium though which many people have the opportunity to learn about sport, and to some degree, New Zealand society.

Although standard sporting biographies focused principally on sport, some were revealing about the personal lives of their subject and alluded to social issues. Published in 1963 when "integration" of Maori and Pakeha was the desired policy setting (critics asserted that "integration" in practice meant the assimilation of Maori into Pakeha society), I George Nepia by George Nepia and Terry McLean, gave an insight into the Maori world many of its readers may not have otherwise had. ${ }^{22}$ Focusing on Nepia's tough childhood, and the omission of himself and other Maori players from the All Black team which toured South Africa in 1928, it concluded with a poignant chapter on his children, one of whom died whilst on active service in Malaya ${ }^{23}$ Moreover, he unapologetically explained his decision to play rugby league (until rugby became professional in 1995 switching from rugby to rugby league was widely regarded as heresy in New Zealand), explaining that he and his family needed the money and that he enjoyed the game. ${ }^{24}$ While Colin Meads: All Black was primarily about rugby, Meads also spoke at some length on racial inequality in New Zealand at a time when the dominant narrative held that New Zealand had the best race relations in the world. He questioned if New Zealanders were aware of the state in which many Maori were living in New Zealand critiquing "the hypocrites who make the same old polite, meaningless sounds about Maoris but who wouldn't lower themselves to mix with Maori on a Maori footing." 25

For the most part, however, sporting biographies and tour books reinforced the dominant narratives about the centrality of sport, particularly rugby, in New Zealand society. Indeed, it might be argued that by virtue of their wide readership they played an important role in perpetuating such views. Brittenden's statement "Rugby, horse racing and trotting, yachting, tennis, skiing, cricket, golf, swimming and motor racing are not so much supported as worshipped" encapsulated the place of sport in postwar New Zealand. ${ }^{26}$ For many writers, sport provided moments, however ephemeral, where New Zealanders excelled. Representative of these is McLean's comment on the All Blacks beating a strong London Counties team on their 1963-64 tour "it was good to be a New Zealander that day. We might have our faults as 
individuals and as a nation, but by heaven we could play Rugby." ${ }^{27}$ Key New Zealand sporting values, such as humility and pride in representing New Zealand, were constantly affirmed, as exemplified in Alex Veysey's statement that Meads was "a bloke who never sought greatness but who just wanted to be an All Black."28

\section{Subverting the Paradigm: The Indirectly Confessional Biography}

The format established by McLean and Brittenden remained dominant until the late 1980s. Between the 1970s and mid-1980s, however, a number of biographies were published which differed from the established format. Three particularly significant works in this regard were Chris Laidlaw's Mud in Your Eye (1973), Graham Mourie and Ron Palenski's Graham Mourie, Captain (1982) and Andy Haden's Boots'n All (1983). These works were published at a time when rugby's hitherto largely uncontested status as the national game was increasingly debated. ${ }^{29}$ In addition to reflecting changing attitudes to sport, these books also reflected the emergence of a generation of players willing to openly challenge the sporting establishment. The iconoclastic Mud in your Eye by Chris Laidlaw led the charge. Although some previous fictional works, such as Gordon Slatter's novel The Pagan Game, had criticized the male chauvinism of rugby, Laidlaw's book carried the imprimatur of being written by a former All Black half-back (Chris Laidlaw played for the All Blacks between 1963 and 1970) and Rhodes Scholar. ${ }^{30}$ There was no account of his childhood and his ascent to sporting fame and commentary on the matches he had played formed only part of the narrative. Laidlaw's primary concern was to place his own experiences of Rugby within the wider context of contemporary social and political changes. Its second chapter "Innocence at Large" condemned the culture of junior rugby in New Zealand, particularly the way overzealous parents and the pressure placed on them to win made the game unenjoyable for children. ${ }^{31}$ The following chapter lamented the "rigid code that demanded a sameness among all the players" that he encountered upon being selected for the All Blacks, extending an earlier observation "conformity is the cornerstone of New Zealand society." 32 Laidlaw also gave a frank assessment of life as a sporting tourist. While not naming names, the chapter "When the Circus Comes to Town: discussed womanizing and vandalism on rugby tours. ${ }^{33}$

Graham Mourie, Captain and Boots'n All also challenged the amateur rugby establishment of which both authors had been a part. The very act of writing these books posed a challenge to the NZRFU. Because Mourie accepted payment for his book, something which was then outlawed under the International Rugby Board's amateur regulations, he was barred from rugby on the grounds of being a professional. Mourie, who captained New Zealand between 1977 and 1982, deviated from the norms of sporting biographies with a detailed explanation of his decision to stand down from the All Black captaincy during the Springbok Tour of $1981 .{ }^{34}$ Andy Haden, a lock forward who played 117 games for New Zealand between 1972 and 1985, wrote extensively about vandalism on rugby tours in a chapter entitled "Smashing Experiences" and much of his book was devoted to his clashes with the NZRFU accompanied by forthright assessments of coaches (one chapter was entitled "Learning to Live with Coaches"), and trenchant criticism of sensationalist media (in the chapter "A Critical Look at the Critics"), while another chapter openly discussed plans for a professional rugby circuit. ${ }^{35}$ This chapter (entitled "The Professional Approach") saw Haden investigated by the NZRFU for allegedly advocating professionalism, an assertion he defended with assistance from Stephen Temm QC. ${ }^{36}$ Such works pointed the way towards the more revelatory biographies of the 1990s but were not in themselves revealing at a personal level. Neither Haden or Mourie named individuals involved in off-field indiscretions and despite their criticisms of the rugby establishment they were generally measured in their assessment of their teammates. ${ }^{37}$ 


\section{Transforming the Genre: The openly confessional approach}

From the mid-1980s, sporting biographies took on a more openly confessional aspect. Whereas disputes within a team had previously been alluded to in general terms, biographies now named names and gave explicit details on what had previously been "behind the scenes" activities. More than simply a change in literary form, these biographies challenged one of the fundamental creeds of New Zealand sport, the belief that "what goes on tour stays on tour." 38 This notion reflected what Jock Phillips called the "unofficial" culture of New Zealand sport, where team rituals provided one of the few spaces for deviant behavior in an otherwise ordered and conformist society. ${ }^{39}$ The changing nature of biographies may also have reflected two underlying and interconnected trends: the growing public interest in sporting personalities, which would see athletes increasingly referred to as "celebrities" from the 1990s and the more individualistic, market-oriented attitudes which became more prominent in public discourse during the 1980s and 1990s. In 1988 Andy Haden, who experienced the growing media interest in sport first-hand during the 1980s, and had considerable contacts within the commercial sector himself, wrote that before the advent of television:

All Blacks were just names in newspaper articles or radio broadcasts, virtually anonymous to those people who didn't go to matches.... Only the very best and longest serving members of the New Zealand national team became household names. Television changed all that; top players were now "under the microscope."

Interest in sports personalities was not confined to television. From the 1980s magazines such as North and South and Metro included lengthy articles on sports stars, which were primarily aimed at letting readers see the person behind the player. ${ }^{41}$

Cricket biographies became much more numerous during the 1980s. This partly reflected the improved performances of the men's team who beat the world champion West Indies in the 1979-1980 test series and made the final of Australia's World Series Cricket competition the following year. Their controversial loss in the fourth match of this series, when Australian captain Greg Chappell instructed his brother Trevor to bowl an underarm delivery to deny New Zealand the opportunity to hit the six runs they needed to tie the match, attracted prime ministerial comment and made cricket a front-page sport. The reinvigorated trans-Tasman rivalry and, possibly, the more individualistic nature of cricket as a sport, provided ample material for more revelatory sporting biographies, particularly those by Jeremy Coney, Glenn Turner and Richard Hadlee. ${ }^{42}$ The frequency with which sporting biographies were now being published created something of a soap opera element around the material, with the same incidents and interpersonal conflicts being revisited in successive publications. Written in association with Ron Palenski, Jeremy Coney's The Playing Mantis was a mixture of the indirectly and openly confessional. While not detailing Coney's personal life, unusually for a sporting biography it detailed the mental turmoil experienced by a test captain and the chapter discussing the atmosphere of the dressing room ("The Stage Door") was the first to take the reader inside the inner sanctum. In other sections, Coney was more direct in his assessments of teammates, particularly in his discussion of how Richard Hadlee's decision to keep a car he had won as a prize on the 1985-86 tour of Australia (previously prizes had been sold and the proceeds shared among teammates) had undermined team unity. ${ }^{43}$ Established as New Zealand's finest bowler by the 1980s, Hadlee gave his own assessment of Coney's captaincy in his 1989 biography Rhythm and Swing in which he revealed how, after an argument with then captain Coney before the third test of the 1986-87 series against the West Indies, he and Coney communicated through an intermediary, John Wright, on the opening morning of the test match. ${ }^{44}$ It is testament to the burgeoning genre of the sports biography that Rhythm and Swing was the seventh book in which Hadlee featured as either the subject or 
author during the 1980s. ${ }^{45}$ In terms of the genre itself, Hadlee Hits Out (published in 1983) and At the Double (1985) were notable for their frank assessment of players and in the case of At the Double, for the detailed discussion of how Hadlee coped with the mental challenges of being a professional sportsperson by utilizing the services of psychologist Grahame Felton. Glenn Turner's four books encompassed both the chronology and confessional periods. My Way (1975) and Century of Centuries (1983) focused on his sporting experiences, but in Opening Up (1987) Glenn Turner gave his perspective on the dispute with the New Zealand Cricket Council which saw him unavailable for New Zealand Cricket between 1978 and 1983 and commented extensively on his antipathy towards members of Australian cricket teams he had encountered. ${ }^{46}$ By the time Lifting the Covers, in which Turner discussed his later removal as national team coach, was published in 1998, such works had become commonplace. ${ }^{47}$

By the 1990s autobiographical publications were taking a visual form with the arrival of the video era seeing the All Blacks packaged for the viewing public in titles such as The Good, The Bad and the Rugby, The Wyllie Bunch and The Day of the Tackle produced by All Black winger John Kirwan in association with Ric Salizzo. ${ }^{48}$ While such videos purported to offer the viewer an inside look at the All Blacks ("The only way you'll get a closer look at the All Blacks is if you're picked to join them," promised the dust cover of The Good, the Bad and the Rugby), they fall outside the confessional category. They presented the All Blacks very much as they wanted to be seen. The emphasis being upon the good clean fun and japes accompanying an All Black Tour rather than the undercurrents of team disharmony later discussed in player biographies (although the scene in The Good, The Bad and the Rugby where John Schuster discusses his prospects about converting to league proved prophetic, Schuster being one of five players from the touring party who would later turn to rugby league). ${ }^{49}$

By the 1990s rugby biographies were following the more openly confessional style of their cricketing counterparts. John Kirwan's Running on Instinct, written in association with novelist Paul Thomas and published in 1992 was a landmark in the field, particularly in its open appraisal of the reasons for the All Black defeat in the 1991 world cup semi-final and for its honesty in portraying John Kirwan the man, as well as John Kirwan the player. One chapter in the book was devoted to his battle with depression. ${ }^{50}$ As Jock Phillips and others have noted, All Blacks have traditionally been regarded as the epitome of New Zealand manhood, so for an All Black to admit to suffering from mental illness was unprecedented and the publicity following his book did much to facilitate open discussion of mental illness, a field with which John Kirwan has remained involved. ${ }^{51}$ The All Blacks' defeat in the 1991 World Cup featured as something of a morality play in rugby biographies during the 1990s, as players admitted to disharmony among the team and coaching staff and, particularly contrary to the All Black ethos of always placing the team first, selfishness and a lack of fitness among some players. ${ }^{52}$ Similarly, cricket biographies in the 1990 s referred to two seminal events. The first was the decision to continue with the 1992 Sri Lankan tour after a bomb had exploded near the team hotel, an event which resulted in many of the team initially wanting to return home. The fallout from this incident was identified by many players as the catalyst for the poor performances of the New Zealand men's cricket team for much of the 1990s. ${ }^{53}$ The second incident involved alleged marijuana smoking on the 1994 New Zealand Cricket tour of South Africa which saw three players temporarily suspended by New Zealand Cricket after the team had returned to New Zealand. Many players discussed this incident, particularly the way in which it was reported to administrators in New Zealand Cricket after the tour had concluded, thereby breaking the sporting creed "what goes on tour, stays on tour." 54 No longer was a sporting biography a record of a player's career, it was now a self-justificatory forum for 
players to convey their version of the incidents in which they had been involved and parade their credentials as committed New Zealand athletes.

By the twenty-first century confessional biographies had become the norm and the literary style of the genre was also evolving. This may have reflected the changing nature of biographers as well as the growing media interest in sport. Whereas until the 1980s sporting biographies were written almost exclusively by sports journalists, since the 1990s many have been written by authors from a literary background (in addition to their sporting interests, these authors may also have been attracted by the marketability of sports biographies). Paul Thomas, author of a series of crime novels wrote biographies of John Wright, John Kirwan, John Hart and Tana Umaga. Brian Turner, a poet and former New Zealand hockey representative, wrote two biographies in association with his brother Glenn Turner and very successful biographies of Colin Meads, Josh Kronfeld and Anton Oliver. ${ }^{55}$ Angus Gillies, a novelist, has written biographies of Matthew Ridge, Adam Parore and Justin Marshall, and Greg McGee, a former Junior All Black and author of Foreskin's Lament, a landmark play criticizing the male chauvinism and homophobia of rugby, wrote the best-selling biography of Richie McCaw. ${ }^{56}$ Possibly because of their expertise in constructing characters, these authors delved much more deeply into the psyche and motivations of their subjects. They also subverted the standard chronological format and included, verbatim, voices critical of their subjects. Angus Gillies' biographies extensively used multi-vocality. In his biography of Matthew Ridge (1998) he devotes considerable space to verbatim extracts from the court case in which Matthew Ridge was charged with aggravated robbery, a charge of which he was acquitted after a successful appeal. In addition to extracts from court documents, Gillies interviewed the complainant and the detectives involved in the case and includes extracts from these interviews in the book. These extracts are rendered in different type from the text of Ridge's story to alert the reader to the different perspectives. Whereas a biographer in an earlier era might have excised this material, or at the very least included some editorial comment reconciling contradictory accounts in favour of their subject, Gillies invites readers to draw their own conclusions. ${ }^{57}$ Even biographies that were not so revealing about their subjects personal lives, such as Richie McCaw's The Open Side, were honest in their appraisal of performances. Whereas many accounts of the All Blacks unexpected loss against France in the quarter-final of the 2007 Rugby World Cup blamed referee Wayne Barnes for the defeat, McCaw acknowledged that the mistakes he and his teammates had made were primarily responsible for the defeat. ${ }^{58}$ The increasing prominence of players of Pacific Island ancestry was also reflected in biographies. Jonah Lomu, perhaps the first rugby player to become a global celebrity, published his biography in 2004 and openly discussed his difficult childhood in South Auckland and how living in the public spotlight affected him. ${ }^{59}$ Tana Umaga, the first player of Pacific Island ancestry to captain the All Blacks, wrote a biography in which in addition to discussing his career, he explained the expectations he and other Pacific Island players were under to contribute towards extended family. ${ }^{60}$ The increasingly open nature of New Zealand sporting biographies reflected international trends in the genre. Andre Agassi's 2009 biography Open in which he admitted hating the game and freely discussed his personal relationships is typical of the modern sporting biography. ${ }^{61}$

The notion that representing New Zealand in sport was the ultimate experience was also challenged. Black and Blue by David Kirk, who captained the All Blacks when they won the 1987 World Cup, openly stated he had retired at the early age of 26 because he no longer enjoyed the conformist team culture, particularly binge drinking. ${ }^{62}$ Unusually for an All Black, Kirk revealed he had cried after his teammates criticized him for declining to tour South Africa with the unofficial Cavaliers team in 1986 (Kirk and John Kirwan were the only first choice All Blacks not to join the Cavaliers, who visited South Africa after the proposed All Black tour in 
1985 was cancelled because of legal action). ${ }^{63}$ Moreover, unlike other coaches who devoted entire biographies to justifying their coaching record, Kirk openly acknowledged his failures as a coach, both in selection and his management of key relationships during his brief tenure as coach of Wellington. ${ }^{64}$ If Kirk challenged some cherished assumptions, Gladiator, the account of Norm Hewitt's career, was perhaps, the most iconoclastic work on New Zealand sport since Mud in Your Eye. It captured the raw reality of rugby in the professional era, lamenting that players were simply a "piece of meat" to many coaches and administrators (or "fishheads" as they were labelled). ${ }^{65}$ Among other things, Hewitt openly documented the demeaning treatment he, and new All Blacks, received from senior players; the racism he had experienced in rugby and his struggles with alcohol. Unlike many sporting biographies, even those within the "confessional" genre, Gladiator refuted platitudinous notions that sport engendered "selfsacrifice" and "loyalty" among players. ${ }^{66}$ Despite its unsparing examination of life as a professional sportsperson there was a redemptive element to the book in its account of how Hewitt reconnected with Tikanga Maori and found stability in his personal life. ${ }^{67}$

\section{Mixing Politics and Sport: Discussing Sporting Contacts with South Africa}

The indirectly confessional era coincided with increasing protest over sporting contacts with South Africa. Whereas during the 1960s protest had focused on the omission of Maori players from New Zealand teams to South Africa, by the 1970s the anti-apartheid movement had changed their focus. The abolition of apartheid, rather than merit-based selection of South African teams became the primary driver. ${ }^{68}$ Consequently, a hitherto absent political element became incorporated into sporting biographies, implicitly challenging the often stated notion that politics should be kept out of sport. Terry McLean's stance on sporting contacts changed markedly in this time. In 1960 he had been in favour of the tour despite the omission of Maori players. ${ }^{69}$ After the 1970 tour, however, he was much more critical of apartheid and argued sporting contacts between New Zealand and South Africa should not continue while it remained in place. ${ }^{70}$ Sporting contacts with South Africa also caused division within Rugby. Ken Gray and Bob Burgess indicated they would be unavailable to tour South Africa in 1970 on moral grounds and as noted Graham Mourie stood down from the captaincy of the All Blacks during the 1981 Springbok tour because of his opposition to apartheid (as did Bruce Robertson who had toured South Africa in 1976). In a chapter "Take up the White Man's Burden," Chris Laidlaw also challenged the morality of sporting contacts with South Africa. ${ }^{71}$

Those in favour of continuing sporting contacts with South Africa explained their reasoning in their biographies. Although not explicitly framed as such, many of these works represented a counter-narrative to the anti-apartheid movement, deploying notions of bridgebuilding and liberalism. Players, especially those of Maori and Polynesian ancestry, argued they were well-received by the non-white peoples of South Africa and that the presence of multi-racial teams in South Africa in 1970 and 1976, some of whom played teams comprising Black and Coloured opponents, was helping to break down racial barriers. Moreover, they argued, that by playing against South Africa they were exercising principles such as freedom of association which were central to New Zealand society. ${ }^{72}$

\section{Diversification of the Genre: The "Cult of the Coach"}

It was not only the character of sporting biographies that changed, their subject matter also diversified to incorporate coaches and support staff. Although New Zealand sporting folklore has a gallery of famous coaches, the emergence of the coach as a subject for sporting biographies is a relatively recent development. Until the 1990s, books by New Zealand coaches tended to be coaching manuals, such as Arthur Lydiard's Run to The Top, Fred Allen on Rugby and Lois Muir on Netball..$^{73}$ These works focused on the technical aspects of sport 
rather than their relationships with their players and the administrators (although Arthur Lydiard's books are something of an exception here as he tended to illustrate his points with reference to athletes such as Peter Snell and Murray Halberg whom he had coached). ${ }^{74}$ Indeed, the relative lack of recognition accorded coaches was cited in 1987 by Joseph Romanos as the justification for his book Makers of Champions: Great New Zealand Coaches. ${ }^{75}$ His reasoning was valid. Even well-known All Black coaches such as Neil McPhail, under whose guidance the All Blacks defeated Wales for the first time at Cardiff Arms Park and Jack Gleeson, the first All Black coach to achieve a Grand Slam (defeating all four home unions on a Rugby Tour) did not write autobiographies. Nor, despite her 15 year tenure coaching the New Zealand Netball team did Lois Muir publish a biography. The earliest books focusing on the coach as personality featured coaches from basketball and rugby league, two minority sports which received extensive television coverage during the 1980s. Technical Foul by John Dybvig and Tom Hyde, published in 1983, was a searing critique of the administration and umpiring of New Zealand basketball and amateur sport in New Zealand more generally. ${ }^{76}$ Three years later, Lowe and Behold, Richard Becht's biography of Graham Lowe, coach of the New Zealand rugby league team between 1983 and 1986, appeared. ${ }^{77}$ It is reflective of the changing nature of New Zealand sport that a biography of a rugby league coach was published at all. League, previously very much in the shadow of rugby union, received considerable publicity after the New Zealand team recorded notable victories over Australia and Great Britain and the iconic song "Give'em a taste of Kiwi" was used in association with the game. ${ }^{78}$

To some degree, the paucity of coaching biographies reflected the prevailing ethos of amateurism in New Zealand sport. Full-time coaches of national teams, let alone representative teams were rare before the 1990s and controversies over appointment of coaches, such as Otago's very successful rugby coach Vic Cavanagh missing out on coaching the All Blacks to South Africa in 1949, were infrequent. By the 1990s, however, as New Zealand sport advanced towards the professional era, coaching positions became subject to intense public debate, particularly the position of All Black coach. When Brian Lochore retired after the 1987 Rugby World Cup the two outstanding candidates for his position were Auckland's John Hart (who had coached Auckland to National Provincial Championship (NPC) titles in 1982, 1984 and 1985 and won the Ranfurly Shield in 1985 and Alex "Grizz" Wyllie who presided over 25 successful defences of the Ranfurly Shield between 1982 and 1985 and Canterbury winning the NPC title in 1983. Wyllie held the position of All Black coach between 1988 and 1991 before being succeeded by Otago's Laurie Mains, who served between 1992 and 1995 after which John Hart became coach between 1996 and 1999. Debate about the merits of the pair was influenced by provincial undertones. Wyllie, an uncompromising former All Black from Canterbury, was viewed as epitomizing the rural "heartland" of New Zealand rugby while John Hart, who worked for Fletcher Challenge, was associated with the corporate class who, in the era of economic liberalization ushered in by the Fourth Labour Government and continued by the National Party, radically transformed New Zealand (his time as Auckland coach coincided with the popularization of the pejorative phrase JAFA - which might be loosely rendered Just Another Fornicating Aucklander). From the 1990s coaching biographies had an element of the political manifesto with coaches putting their credentials before the sporting public, highlighting their role in successful campaigns and mitigating their role in unsuccessful ones. Written in collaboration with Phil Gifford, Grizz: The Legend published before the 1991 Rugby World Cup was the first biography written by a serving All Black coach. As well as relaying the life of its subject, Gifford defended Wyllie against criticisms of his coaching. ${ }^{79}$ Two years later, the first of John Hart's biographies, Straight from the Hart, was published. Subtitled "The Career and Philosophy of a Revolutionary Rugby Coach," the book read as an elegy to an exiled leader, extolling Hart's achievements as a coach, denying 
assertions he had been a Machiavellian influence in New Zealand rugby and excoriating the processes which had twice seen him overlooked for the position of All Black coach in 1988 and $1991 .^{80}$ If Straight from the Hart read like a lament for the lost, Change of Hart, published in 1997, read like a redemption narrative in which the by now rightfully installed coach explained in comprehensive detail how he had presided over a first ever test series victory against South Africa in South Africa in 1996 and two successful tri-nations campaigns. Perhaps fortunately, from the perspective of its subject, the book was published before the All Blacks, under Hart's coaching, lost five successive test matches in 1998 and lost to France 3143 in the semi-final of the 1999 world cup. ${ }^{81}$ This defeat occasioned a particularly vituperative response among sections of the sporting public. ${ }^{82}$ The 1990s saw the emergence of what might be termed "exile narratives" from coaches whose tenure with New Zealand representative teams had concluded. In addition to Glenn Turner's Lifting the Covers, published in 1998, the late 1990s also saw Geoff Howarth and Graham Henry publish biographies. It is reflective of the public interest in coaches that Howarth's Stirred but not Shaken focused not on his extremely successful captaincy of the New Zealand cricket team during the 1970s and 1980s, in which New Zealand recorded maiden test series wins over the West Indies and England, but on his much less successful period as coach of the New Zealand cricket team which included the controversial tour to South Africa in $1994 .{ }^{83}$ Graham Henry's first biography The X Factor was published shortly after he had left New Zealand to coach Wales in 1998, an action which saw the New Zealand Rugby Union adopt the so-called "Henry Clause," under which New Zealanders who coached national teams of other countries were deemed ineligible to coach the All Blacks. ${ }^{84}$

The way in which coaches treated their players was an ongoing narrative in sporting biographies. Indeed, such was the increasingly revelatory nature of biographies that from the 1990s a significant portion of many biographies was devoted to responding to comments by other players, so there was a sense in which they were generating a self-perpetuating narrative. A number of players, including Norm Hewitt and Josh Kronfeld, criticized aspects of Hart's coaching and his conduct towards players, particularly what they regarded as his excessively managerial style. ${ }^{85}$ Hart's biographer Paul Thomas responded to some of these in his 2003 book A Whole New Ball Game, the ostensible focus of which was the impact of professionalism upon New Zealand rugby. ${ }^{86}$ Thomas approvingly quoted a statement by John Mayhew, All Black Doctor between 1988 and 1994 and 1996-2003 that he "gave up reading players books" because he believed much of their content was incorrect. ${ }^{87}$ Notwithstanding his reservations about the genre, Mayhew published his own book in 2004, the first member of a national team support staff who was not a coach, to do so. The focus of the book was not on his role as doctor (commentary on which is concentrated in one chapter) but assessments of the players and coaches he had served. ${ }^{88}$

\section{A Gendered Genre? Women and Families in Sporting Biographies}

Although New Zealand women have been involved in sport for more than 150 years, there have been relatively few biographies of New Zealand sportswomen. Because the games men play, particularly rugby (which until the 1980s was an almost exclusively male sport), are the sports most closely linked to national identity, and because men's sport dominates media coverage, biographies of male sportsmen may have been seen as more commercially viable. ${ }^{89}$ The early biographies of sporting women focused on people who were prominent in the news and the public sphere. The first biography of a New Zealand female sportsperson appears to be No Grass Between my Toes: The Eve Rimmer Story, which was published in $1978 .{ }^{90}$ Rimmer was a paraplegic athlete who won many gold medals representing New Zealand at Olympic and Commonwealth Paraplegic Games and was a vigorous advocate for disabled people. Her 
biography was a candid account of the everyday difficulties she faced and the prejudice experienced by the disabled community as well as discussing her sporting achievements. ${ }^{91}$ The Linda Jones Story, published in 1979, focused extensively on Jones's battle to be admitted as an apprentice jockey so that she could race against male professionals. Her case was extensively discussed in the media and after considerable public pressure (MP Marilyn Waring wrote to the New Zealand Racing Conference (NZRC) advising them that denying licenses to female jockeys would be illegal under forthcoming Human Rights legislation); the NZRC allowed women to become licensed as professional jockeys in $1977 .{ }^{92}$ Jones's biography was the first in New Zealand to discuss gender discrimination in sport and it reflected the causes then actively espoused by the feminist movement in New Zealand. ${ }^{93}$

Netballers feature prominently in biographies of New Zealand sportswomen, reflecting its status as the most widely publicized women's sport and, possibly, its historical standing as the sport deemed most 'appropriate' for women. ${ }^{94}$ Since Sandra Edge's Full Circle appeared in 1995, Bernice Mene, Irene van Dyk and Adine Wilson have published biographies. ${ }^{95}$ Bernice Mene's career usefully illustrates the increasing crossover between sport and the entertainment industry since the 1990s. In consultation with Glenda Hughes, a former national shot-put champion and policewoman who acted as a media strategist for many athletes, Mene announced her decision to retire from the Silver Ferns in an exclusive interview with the Australian Women's Weekly in 2002. She was able to leverage her profile as a player to secure endorsements, leading Hughes to suggest she may be seen as "the first example in New Zealand of a planned female sporting career." 96 The biographies of Edge, Mene and Van Dyk were written in a predominantly chronological fashion, focusing primarily on their subject's sporting careers. Irene van Dyk's biography touched on the criticism surrounding her initial selection (she had represented South Africa before settling in New Zealand) but was otherwise primarily netball focused-it was written before her much publicized decision to leave Wellington's Capital Shakers and play for Waikato. ${ }^{97}$

Although most biographies of sportswomen followed the standard format, two recent works by female Olympians can be located within the "confessional" genre. On the Wings of Mercury by athlete Lorraine Moller is unstintingly honest about her relationships with men, both inside and outside of marriage, her perceptions of her rivals, particularly fellow New Zealand athlete Anne Audain and the self-lacerating mental anguish that athletes experience. Her biography is as much about her inner world, recounting the way her self-talk affected her performances and her metaphysical interest in the new age philosophy Seth and the guidance she sought from the Roman God Mercury, as it is about running itself. ${ }^{98}$ As well as discussing her sporting achievements, Valerie, by two-time gold-medalist Valerie Adams, is extremely direct in relaying her perspective on the way her relationship with long-time coach Kirsten Hellier finished, the break-up of her marriage and the negative way she was sometimes portrayed in the media, particularly the criticism she received in response to a television interview she gave after she missed out on qualifying for the final of the shot-put at the 2004 Olympics. ${ }^{99}$

Women and families also began to feature more prominently in biographies of male sportsmen. Previously, most sporting biographies included little information on the players personal and family lives (except insofar as detailing how their families had helped their sporting development and the occasional inclusion of family photos, possibly to reassure readers the subjects were heterosexual and respectably married). John Reid's Sword of Willow is dedicated to his wife Norli and includes a photograph of his family, the caption to which acknowledges the support he received from his wife over the years, but otherwise she is barely mentioned. ${ }^{100}$ If wives and family were peripheral, discussion of relationships outside of 
marriage was completely absent. Some tour books included veiled references to liaisons with women, but these were mostly brief and included for the purposes of providing mildly titillating content or to evaluate the degree to which a team was taking its sporting obligations seriously. ${ }^{101}$ By the 1980s, however, many biographies included chapters devoted to wives and husbands. The first New Zealand sports biography to include a chapter on the player's wives appears to be wrestler Steve Rickard's On the Mat. ${ }^{102}$ The first rugby biography to do so was Stu Wilson and Bernie Fraser's Ebony and Ivory, published in $1984 .{ }^{103}$ In "Those Who Wait," Robyn Wilson and Lynda Fraser criticized the treatment of wives and partners by the NZRFU and the attitudes of many rugby players and supporters. Subsequently, many biographies included a chapter on the players' wives and families. ${ }^{104}$ Rhythm and Swing, by Richard Hadlee included a chapter from his wife Karen entitled "The Better Half" in which she reflected on the pressures of being married to a high profile cricketer. ${ }^{105}$ Such was the trend towards biographies including chapters from players' wives that, Adele Fox, wife of All Black Grant Fox, prefaced her account by noting it had become "fashionable for rugby wives to say their piece in their husbands' books," before recounting the impact the personal abuse directed at Grant Fox had upon herself and their children. ${ }^{106}$ Later, this trend extended to biographies of sports women. Russell Gray's biography of Irene van Dyk included a chapter on her husband Christie and his struggles learning to speak English and adapting to life in New Zealand. ${ }^{107}$ By the 1990s biographies also acknowledged when relationships had ended. Ken Rutherford laid bare the strains of captaining a poorly performing team in his biography, aptly entitled A Hell of a Way to Make a Living, detailing the personal pressures on him and frankly discussing the break-up of his marriage. ${ }^{108}$

\section{Continuities in New Zealand Sporting Biographies}

Despite the changes in the format of New Zealand sporting biographies there are, nevertheless, many elements of continuity. Despite their changing character, they tend to reinforce the dominant discourse that New Zealanders are particularly good at sport and that representing New Zealand is the ultimate sporting experience. ${ }^{109}$ Martin Crowe, whose autobiography Out on a Limb reflected, in part, a sense of alienation from New Zealand male culture emphasized "I've only ever wanted to represent my nation, to wear the silver fern. That's what fulfils me." ${ }^{110}$ Richie McCaw's biography emphasizes his commitment from an early age to be a "Great All Black," recounting how, early in his life, a supportive uncle instructed him to write that phrase in a notebook as a motivational spur. ${ }^{111}$ In an era when, since the mid-1990s, many New Zealand sportsmen, especially Rugby players, earn far more than the average wage, sporting biographies consistently reaffirm the humility of their subjects, presenting them as people who have succeeded by dint of hard work and a willingness to subjugate themselves to the wider good of the team. In so doing, they reinforce one of the key tenets of the present neoliberal consensus in New Zealand: that New Zealand is a meritocratic (if no longer egalitarian) society where anyone can make it. Indeed, although more revealing about the personal experiences of their subjects, New Zealand sporting biographies remain largely apolitical, ignoring almost completely the increasing inequality in New Zealand. ${ }^{112}$

\section{Conclusion}

Despite their changing format, sporting biographies offer a largely uncritical and commercially viable affirmation of New Zealand identity. As such they constitute an important and, to date, largely untapped primary source on changing notions of New Zealand identity because they reflect how many New Zealanders see themselves and want to be seen-as a successful, healthy and unified people. Their popularity makes them particularly significant in this regard, because the images they portray of their subjects and New Zealand society more generally 
reach a wide audience, many of whom may not read more specialist texts. For these reasons, while many remain unconvinced about their literary merits, they are, at the very least, worthy of inclusion in analyses of New Zealand literature and, more widely, New Zealand society.

\footnotetext{
${ }^{1}$ See, for example, Malcolm MacLean, "Some Hope in Rugby Writing but the Blokes are Still in Control," Sporting Traditions 14, no. 1 (1997): 135-45; Lloyd Jones, "The Missing Literature," in Sport, Society and Culture in New Zealand, ed. B. Patterson (Wellington: Stout Centre, Victoria University of Wellington, 1999), 73-78. For a more sympathetic appraisal see Roger Robinson, "Literature, Journalism and Sport in New Zealand," also in Sport, Society and Culture in New Zealand, 135-46.

2 Jones, "The Missing Literature," 73.

${ }^{3}$ James Mortimer, "Richie McCaw the best-selling author?," 16 December, 2012,
} http://www.allblacks.com/News/21269/richie-mccaw-the-best-selling-author, accessed 7 October 2015. Joseph Romanos compiled the following figures for New Zealand sports books: Men in Black, (various editions) 70,000; Alex Veysey, Colin Meads All Black, 57,000 (61,000 including overseas sales), Andy Haden, Boots'n All, 44,000; Graham Mourie and Ron Palenski, Graham Mourie: Captain, 43,000; Jeremy Coney, The Playing Mantis, 42,000; Chris Laidlaw, Mud in Your Eye, 40,000; Alex Veysey, Stu Wilson and Bernie Fraser, Ebony and Ivory, 39,000; Bob Howitt and Sid Going, Super Sid, 33,000; Paul Thomas and John Hart, Change of Hart, 33,000; Paul Thomas and John Hart, Straight from the Hart, 32,000; Alex Wyllie and Phil Gifford, Grizz The Legend, 29,000; Grant Batty and Bob Howitt, Grant Batty, 28,000; Bob Howitt, Rugby Greats (Vol. 1), 27,000; Peter Bush, The Game for All New Zealand, 25,000. Romanos estimated Sean Fitzpatrick's two books Fronting Up and Turning Point sold c. 50,000 copies put together and Graham Henry's The X Factor, in excess of 40,000 copies. Joseph Romanos, "Sport” Listener, 18 December, 1999, 59.

${ }^{4}$ Paul Lewis and Jock McLean, TP: The Life and Times of Sir Terry McLean (Auckland: Harper Collins, 2010), 281.

${ }^{5}$ Marc Ellis, for example, played eight tests for the All Blacks but became well known for his appearances on television shows, including Sports Cafe and In the Deep End, the latter show featuring Ellis and Matthew Ridge. Marc Ellis with Kirsten Matthew, Marc Ellis: Crossing the Line (Auckland: Hodder Moa, 2006). Norm Hewitt played nine test matches but was involved in some highly publicised off-field incidents which he discusses in his biography. Michael Laws, Gladiator: The Norm Hewitt Story (Wellington: Darius, 2001).

${ }^{6}$ Anthony Wilding's biography, On the Court and Off (London: Methuen, 1912) may be the first biography of a New Zealand sportsperson.

${ }^{7}$ Arthur Swan, History of New Zealand Rugby Football 1870-1945: A Complete and Authentic History Compiled under Official Sanction (Wellington: A. H. and A. W Reed, New Zealand Rugby Football Union, 1948).

${ }^{8}$ Tom Ellison, The Art of Rugby Football: With Hints and Instructions on Every Point of the Game (Wellington: Geddis and Blomfield, 1902, reprinted Kiwi, c. 1997).

${ }^{9}$ Ellison, 64-66, 80. See for example "Balls, Bullets and Boots Exhibition," http://ww100.govt.nz/balls-bullets-and-boots-exhibition, accessed 20 October, 2015.

${ }^{10}$ George Williams, Joe Warbrick and Henry Wynyard, compiled by T. Eyton, Rugby Football (Past and Present) and the Tour of the Native Team in Great Britain, Australia and New Zealand, in 188889 (Caxton: Auckland, 1896); George H. Dixon, 1905: The Triumphant Tour of the New Zealand Footballers (Wellington: Geddis and Blomfield, 1906); Mark Nicholls, With the All Blacks in Springbokland 1928 (Wellington: L. T. Watkins, 1928). In addition, the captain and vice-captain of the 1905 All Blacks, Dave Gallaher and J. W. Stead, wrote a book on rugby shortly after the tour concluded. D. Gallaher and J.W. Stead, The Complete Rugby Footballer on the New Zealand System (London: Methuen, 1906). 
${ }^{11}$ R. A. Barr, British Rugby Team in Maoriland: True Story of the Tour (Dunedin: Otago Daily Times and Witness Newspaper Company, 1908). Denis Lalanne, La Melee Fantastique: The French Rugby Tour of New Zealand 1961 (Wellington: A. H. and A. W. Reed, 1962). E.J. Boyd Wilson from Victoria University translated this book into English as well as Lalanne's book The Great Fight of the French Fifteen on the 1958 tour by the French rugby team to South Africa

${ }^{12}$ Dan Reese, one of New Zealand's best cricketers of the early twentieth century, published his autobiography in 1948. Perhaps because it was initially intended primarily as a family record Reese included an extensive discussion on his career in commerce. Dan Reese, Was it all Cricket? (London: Allen and Unwin, 1948).

${ }^{13}$ Lewis and McLean, TP, 115-30.

${ }^{14}$ Bert Sutcliffe had returned to the batting crease, head swathed in bandages after being struck on his unprotected head by a bouncer from Neil Adcock and Bob Blair was not expected to bat because he had learned just before the start of play that his fiancé was one of the 151 people killed in the Tangiwai train disaster on Christmas Eve 1953. R. T. Brittenden, Silver Fern on the Veld: New Zealand Cricketers in South Africa 1953-54 (Wellington: A. H and A. W. Reed, 1954), 109-14.

${ }^{15}$ Terry McLean, Bob Stuart's All Blacks (Wellington: A. H. and A. W. Reed, 1954). R. W. H. Scott and Terry McLean, The Bob Scott Story (Wellington: A. H. and A. W. Reed, 1956).

${ }^{16}$ See for example, Andy Haden, Boots' $n$ All (Auckland: Rugby Press, 1983), 126; Lewis and McLean, $T P, 13$.

${ }^{17}$ See for example, Terry McLean, All Black Power: The Story of the 1968 All Blacks in Australia and Fiji and the 1968 French Team in New Zealand and Australia (Wellington: A. H. and A. W. Reed, 1968), 43, 159, and Terry McLean, They Missed the Bus: Kirkpatrick's All Blacks of 1972-73 (Wellington: A. H. and A. W. Reed, 1973), 7.

18 Lewis and McLean, TP, 14.

${ }^{19}$ Arthur Lydiard and Garth Gilmour, Run to the Top (Wellington: A. H. and A. W. Reed, 1962; Garth Gilmour, Run for Your Life. Jogging with Arthur Lydiard (Auckland: Minerva, 1965).

${ }^{20}$ Joseph Romanos' biography of Martin Crowe Tortured Genius (Auckland: Hodder Moa Beckett, 1995).

${ }^{21}$ Garth Baker, "Becoming Heroic," New Zealand Books 23, no. 1 (2013), 24. Garth Baker, "All Credit to the Team," New Zealand Books 14, no. 1 (2004), 2-3. Baker's 2013 article reviews the biographies of McCaw and Adams. The 2004 article reviews three books on the history of New Zealand rugby, John Matheson's biography of Christian Cullen and Paul Thomas' book A Whole New Ball Game on the impact of professionalism on New Zealand rugby.

${ }^{22}$ James Belich, Paradise Reforged: A History of the New Zealanders from the 1880s to the Year 2000 (Auckland: Allen Lane, 2001), 476-77.

${ }^{23}$ George Nepia and Terry McLean, I George Nepia: The Golden Years of Rugby (Wellington: A. H. and A. W. Reed, 1963), 15-19; 135-40, 153-58; 189-94.

${ }^{24}$ Nepia and McLean, I George Nepia, 180-88.

${ }^{25}$ Alex Veysey, Colin Meads All Black (Auckland: Collins, 1974), 170. See pages 170-4 for his discussion of race relations in New Zealand.

${ }^{26}$ Brittenden, Silver Fern on the Veld, 28.

27 Terry McLean, Willie Away: Wilson Whineray's All Blacks of 1963-64 (Wellington: A. H. and A. W. Reed, 1964), 53.

${ }^{28}$ Veysey, Colin Meads: All Black, 16.

${ }^{29}$ A number of writers expressed concern about the conduct of the All Blacks during their 1972-73 tour of the United Kingdom, during which Keith Murdoch became the first All Black to be sent home. See, for example, Terry McLean, They Missed the Bus, 6-11, 29-45, 106-112. Alex Veysey also talked about a "sickness of spirit," in New Zealand Rugby. Veysey, Colin Meads: All Black, 27. See also Terry McLean, All Blacks Come Back: Terry McLean Looks at New Zealand and World Rugby (Wellington: A.H. and A.W. Reed, 1975), 14. The incident involving Murdoch was discussed in a number of biographies. See, for example, Lindsay Knight, (Auckland: Rugby Press, 1969), 99-114; 
Bob Howitt, Super Sid: The Story of a Great All Black (Auckland: Rugby Press, 1978), 182-83; Bob Howitt, Beegee: The Bryan Williams Story (Auckland: Rugby Press, 1981), 98-110. The incident has also inspired the play, Finding Murdoch, about journalist Margot McRae's search for Keith Murdoch, which was first performed in 2008.

${ }^{30}$ Gordon Slatter, The Pagan Game (London: Robert Hale, 1968). See Robinson, "Literature, Journalism and Sport in New Zealand," 143-44, for a discussion of The Pagan Game.

${ }^{31}$ Chris Laidlaw, Mud in Your Eye: A Worm's Eye View of the Changing World of Rugby

(Wellington: A. H and A. W. Reed, 1973), 13-19.

${ }^{32}$ Laidlaw, Mud in Your Eye, 26, 25.

${ }^{33}$ Laidlaw, Mud in Your Eye, 53-66.

${ }^{34}$ Graham Mourie and Ron Palenski, Graham Mourie, Captain (Auckland: Moa Beckett, 1982; reprinted Auckland: Whitcoulls, 1994), 25-45.

${ }^{35}$ Haden, Boots' $n$ All, 70-78, 206-21, 79-111, 120-34, 222-39.

${ }^{36}$ Andy Haden, Lock, Stock'n Barrel (Auckland: Rugby Press, 1988), 22-41.

${ }^{37}$ See for example Mourie and Palenski, Graham Mourie, Captain, 185-86.

${ }^{38}$ Angus Gillies, Adam Parore: The Wicked Keeper (Auckland: Penguin, 2002), 85.

${ }^{39}$ Jock Phillips, A Man's Country? The Image of the Pakeha Male-A History (Auckland: Penguin, 1987), 82-130.

${ }^{40}$ Haden, Lock Stock'n Barrel, 22.

${ }^{41}$ See, for example, Margot Butcher, "Flash Harry," North and South (March 1993), 78-86; Lloyd Jones, "Spin Doctor," Metro (March 1993), 46-52. The articles were on Chris Harris and Dipak Patel respectively.

${ }^{42}$ Glenn Turner and Brian Turner, Opening Up (Auckland: Hodder and Stoughton, 1987); Richard Hadlee and Richard Becht, Rhythm and Swing (Auckland: Moa, 1989); Jeremy Coney, The Playing Mantis (Auckland, Moa, 1986).

${ }^{43}$ Coney, The Playing Mantis, 247-52, 122-32, 273-76. Hadlee and Becht, Rhythm and Swing, $127-$ 30 .

${ }^{44}$ Hadlee and Becht, Rhythm and Swing, 61-64; see also pages 58-64 for his critical assessment of Coney as captain. For John Wright's take on the incident see John Wright and Paul Thomas, Christmas in Rarotonga: The John Wright Story (Auckland: Moa, 1990), 186-87.

${ }^{45}$ Richard Hadlee and Dick Brittenden, Hadlee (Wellington: Reed, 1981); Richard Hadlee, Hadlee's Humour (Auckland: Lansdowne, 1982); Richard Hadlee, Hadlee on Cricket: The Essentials of the Game (Wellington: Reed, 1982); Richard Hadlee, Hadlee Hits Out (Auckland: Lansdowne, 1983); Richard Hadlee, Francis Payne, and Dick Brittenden, The New Zealand Cricketer's Who's Who (Christchurch: Whitcoulls, 1985, reprinted 1987); Richard Hadlee, At the Double: The Story of Cricket's Pacemaker (Auckland: Hutchinson, 1985); Hadlee and Becht, Rhythm and Swing.

${ }^{46}$ Glenn Turner and Brian Turner, Opening Up, especially 34-61, 86-97.

${ }^{47}$ Glenn Turner first served as cricket manager of New Zealand between 1985 and 1987. His second term as coach of the national team was between 1995 and 1996.

${ }^{48}$ John Kirwan and Paul Thomas, Running on Instinct (Auckland, Moa and Beckett, 1992), 219-32. According to Kirwan, almost 50,000 copies of The Good, The Bad and The Rugby were sold. The Good, The Bad and the Rugby was made in 1990; The Wyllie Bunch and The Day of the Tackle in 1991.

${ }^{49}$ The other players from the touring party who left rugby union to play rugby league were Matthew Ridge, John Gallagher, John Timu and John Kirwan.

${ }^{50}$ Kirwan and Thomas, Running on Instinct, 151-65, 205-16.

${ }^{51}$ John Kirwan has fronted a number of mental health campaigns and has published several books on depression, including John Kirwan and Margie Thomson, All Black's Don't Cry: A Story of Hope (Auckland: Penguin, 2010).

${ }^{52}$ See for example, Grant Fox and Alex Veysey, The Game, The Goal (Auckland: Rugby Press, 1992), particularly the chapters "The Reluctant Twins" and "Ghost Busting" where Fox refutes rumours of a 
punch-up between himself and Wayne Shelford. See also Kirwan, Running on Instinct, 151-65; Mike Brewer and Phil Gifford, "The Plague Years," Mike Brewer: The Authorised Biography (Auckland: Rugby Publishing, 1995), 33-53; Sean Fitzpatrick and Steven O'Meagher, Fronting Up: The Sean Fitzpatrick Story (Auckland: Moa, 1994), 9-32.

${ }^{53}$ See for example, Ken Rutherford and Chris Mirams, "That Damn Bomb," A Hell of a Way to Make a Living (Auckland: Hodder Moa Beckett, 1995), 60-74; Chris Pringle, "The Colombo Shuffle," Save the Last Ball for Me (Celebrity Books: Auckland, 1998) 113-22; Mark Greatbatch and James Harding, Boundary Hunter (Auckland: Hodder, Moa Beckett, 1996), 122-27; Martin Crowe, Out on a Limb (Auckland, Reed, 1995), 158-68; Angus Gillies, Adam Parore, 38-46.

${ }^{54}$ Rutherford and Mirams, A Hell of a Way to Make a Living, 135-42 and 151-55; Danny Morrison, Mad as I Wanna Be (Auckland: Hodder Moa Beckett, 1997), 152-88; Pringle, Save the Last Ball for Me, 131-41; Crowe, Out on a Limb, 233-35; Gillies, Adam Parore, 85-87; Richard Boock, Stephen Fleming: Balance of Power (Auckland: Hodder Moa Beckett, 2004), 44-50.

${ }^{55}$ Josh Kronfeld and Brian Turner, On the Loose (Dunedin: Longacre, 1999); Brian Turner, Meads (Auckland: Hodder Moa Beckett, 2002); Anton Oliver, Inside (Auckland: Hodder Moa, 2005).

${ }^{56}$ Greg McGee, Foreskin's Lament (Wellington: Victoria University Press, 1981).

${ }^{57}$ See, for example, Angus Gillies, Matthew Ridge: Take No Prisoners (Auckland: Hodder Moa, 1998), 15-22; 24-27; 29-32; 41-48; 51-55; 57-58; 63-67; 69-70; 72-80; 82-84. See also Gillies' biography of Justin Marshall, particularly the discussion of a court case in which Marshall was involved. Angus Gillies, Justin Marshall (Auckland: Hodder Moa, 2005), 35-47.

${ }^{58}$ Richie McCaw and Greg McGee, The Open Side (Auckland, Hodder Moa, 2012), 15-37, 56-59.

${ }^{59}$ Jonah Lomu, Jonah Lomu: My Story (Auckland: Hodder Moa Beckett, 2004), $23-42$.

${ }^{60}$ Tana Umaga and Paul Thomas, Tana Umaga: Up Close (Auckland: Hodder Moa, 2007), 9-14; $151-$ 64.

${ }^{61}$ Andre Agassi, Open: An Autobiography (London: Harper Collins, 2009).

${ }^{62}$ David Kirk, Black and Blue (Auckland: Hodder Moa Beckett, 1997), 131-34.

${ }^{63}$ Kirk, Black and Blue, 75-93, 99-103.

${ }^{64}$ Kirk, Black and Blue, 161-75.

${ }^{65}$ Laws, Gladiator, 136, 268, 64, 265.

${ }^{66}$ See for example Laws, Gladiator, 11-25, 27, 37, 100-01, 104-07, 115, 140, 152-55, 201-10.

${ }^{67}$ Laws, Gladiator, 212-15, 227, 231-42.

${ }^{68}$ Doug Booth, The Race Game: Sport and Politics in South Africa (London: Frank Cass, 1998), 85122.

${ }^{69}$ McLean, Beaten By the Boks (Wellington: A. H. and A. W. Reed, 1960), 19-26.

${ }^{70}$ McLean, Battling the Boks (Wellington: A. H. and A. W. Reed, 1970), 80-89, 182.

${ }^{71}$ Laidlaw, Mud in Your Eye, 186-98.

${ }^{72}$ See, for example, Bob Howitt, Grant Batty (Auckland: Rugby Press, 1977), 198-202; Howitt, Super Sid, 98, 248; Andy Haden, Boots'n All, 183-91.

${ }^{73}$ Fred Allen and Terry McLean, Fred Allen on Rugby (Auckland: Cassell, 1970); Lois Muir and Joseph Romanos: Lois Muir on Netball (Auckland: Reed Methuen, 1985).

${ }^{74}$ See for example, Lydiard and Gilmour, Run to the Top, 29-33, 155-76.

${ }^{75}$ Joseph Romanos, Makers of Champions: Great New Zealand Coaches (Lower Hutt: Mills, 1987), 232.

${ }^{76}$ John Dybvig and Tom Hyde, Technical Foul (Auckland: Dybvig and Hyde, 1983).

${ }^{77}$ Richard Becht, Lowe and Behold: The Graham Lowe Story (Auckland: Harlen, 1986).

${ }^{78}$ The phrase "Give'em a Taste!" was used in Lion Red advertisements promoting Rugby League. See for example, B. Wood, ed., 1986 Lion Red Rugby League Annual (Wellington: Gyles Printpak, 1986), 3. The cover of Lowe and Behold included the Lion Red logo.

${ }^{79}$ Alex Wyllie, Grizz: The Legend (Auckland: Rugby Press, 1991), 11, 169-72, 237-38.

${ }^{80}$ Paul Thomas, Straight From the Hart: The Career and Philosophy of a Revolutionary Rugby

Coach (Auckland: Moa Beckett, 1993). 
${ }^{81}$ Paul Thomas, Change of Hart (Auckland: Hodder Moa Beckett, 1997).

${ }^{82}$ Greg Ryan, "The End of an Aura: All Black Rugby and Rural Nostalgia in the Professional Era," in Tackling Rugby Myths: Rugby and New Zealand Society 1854-2004, ed. G. Ryan (Dunedin: Otago University Press, 2005), 151-60.

${ }^{83}$ Geoff Howarth and Ian Hepenstall, Stirred but not Shaken (Auckland: Hodder Moa Beckett, 1998).

84 "Return Henry, All is Forgiven," New Zealand Herald, 11 February, 2002. Graham Henry and Bob Howitt, Graham Henry: The X Factor (Auckland: Celebrity Books, 1999), 113.

${ }^{85}$ Laws, Gladiator, 149-65, 184-89; Kronfeld and Turner, On the Loose, 179-91, 210-12, 214-16, 217-18; Oliver and Turner, Anton Oliver, Inside, 58-59, 74, 107.

${ }^{86}$ Paul Thomas, A Whole New Ball Game: Confronting the Myths and Realities of New Zealand Rugby (Auckland: Hodder Moa Beckett, 2003), 193-98.

${ }^{87}$ Thomas, A Whole New Ball Game, 198.

${ }^{88}$ John Mayhew, Doc Mayhew: Rugby's Medicine Man (Auckland: Hodder Moa Beckett, 2004). The chapter "Medically Speaking" discussing sports medicine is 183-93.

${ }^{89}$ Judy McGregor, "The Mass Media and Sport," in Sport and Society in New Zealand, ed. C. Collins (Palmerston North: Dunmore, 2000), 194-97. McGregor's study of six New Zealand newspapers in 1992 and 1996 found that $75 \%$ and 80\% respectively of the sports coverage was on male sport.

${ }^{90}$ Eve Rimmer and Garth Gilmour, No Grass between my Toes: The Eve Rimmer Story (Wellington: A. H. and A. W. Reed, 1978). Subsequent biographies of women followed this pattern. Susan Devoy, New Zealand's most successful squash player, was the subject of the 1993 biography as was Sandy Barwick, a world champion ultradistance runner. Susan Devoy and Robyn Scott-Vincent, Out on Top (Auckland: Moa Beckett, 1993); Sandy Barwick and Garth Gilmour, Unstoppable: The Sandy Barwick Story (Auckland: Harper Collins, 1993).

${ }^{91}$ See for example, Rimmer and Gilmour, No Grass Between my Toes, 21-22, 39, 40-45, 91-97.

${ }^{92}$ Linda Jones and John Costello, The Linda Jones Story (Auckland: Moa, 1979), 57-72.

${ }^{93}$ James Belich, Paradise Reforged: A History of the New Zealanders from the 1880s to the Year 2000, 496-504.

${ }^{94}$ In 2014 Netball New Zealand estimated 354,000 people played netball. Netball New Zealand, Ninetieth Annual Report, 2014, 37. Geoff Andrew, "A Girls Game and a Good One Too: A Critical Analysis of New Zealand Netball," MA Thesis, Canterbury University, 1997. Barbara Cox and Shona Thompson, "From Heydays to Struggles: Women's Soccer in New Zealand," Soccer and Society 4, no. 2-3 (2003): 208.

${ }^{95}$ Sandra Edge and Joseph Romanos, Full Circle (Auckland: Hodder Moa Beckett, 1995); Bernice Mene, Mene Confessions: Tall Tales from Netball's Inner Circle (Auckland: Hodder Moa Beckett, 2000); Russell Gray, Changing Colours: The Irene van Dyk Story (Auckland, Harper Collins, 2002); Adine Wilson and Ron Palenski, Adine Wilson: Skills and Performance (Auckland: Hodder Moa, 2008). Although Wilson's book starts with a discussion of netball skills and tactics, it is mostly biographical.

${ }^{96}$ Glenda Hughes, Looking for Trouble: Behind the Scenes of the New Zealand Media (Auckland: Harper Collins, 2003), 135.

${ }^{97}$ Dominion Post, 11 October, 2002.

${ }^{98}$ See, for example, Lorraine Moller, On the Wings of Mercury: The Lorraine Moller Story (Dunedin: Longacre, 2007), 60, 88, 101-09, 113-35, 147-48, 195-96, 217-19, 225-30.

${ }^{99}$ Valerie Adams and Phil Gifford, Valerie (Auckland, Hodder Moa, 2012), 79-101, 102-17, 184-89.

${ }^{100}$ John Reid, Sword of Willow (Wellington: A. H. and A. W. Reed, 1962), flyleaf, caption opposite 243. Likewise, Veysey's Colin Meads: All Black praised Meads' wife Verna for her support, but otherwise family received little discussion: 15, 89-91.

${ }^{101}$ See, for example, Barr, British Rugby Team in Maoriland, 56, 80-81; McLean, Willie Away, 50.

102 John Mancer, Steve Rickard's Life On the Mat (Auckland: Rugby Press, 1979), 29-36.

${ }^{103}$ Bernie Fraser, Stu Wilson and Alex Veysey, Ebony and Ivory (Auckland: Moa Beckett, 1984; reprinted Auckland: Whitcoulls, 1994), 241-47. 
${ }^{104}$ See for example, "Partners," in Dave Loveridge and Ron Palenski, Loveridge: Master Halfback (Auckland: Moa, 1985), 223-32; "Fate Plays a Hand," in Mike Brewer and Phil Gifford, Mike Brewer, 83-96; Danny Morrison, "You're the Best Thing," in Mad as I Wanna Be, 119-23; Ewen Chatfield and Lynn McConnell, "Life's Partnership," in Chats: Ewen Chatfield's Life in Cricket (Auckland: Moa, 1988), 167-76.

${ }^{105}$ Hadlee and Becht, Rhythm and Swing, 263-76.

${ }^{106}$ Fox and Veysey, The Game, The Goal, 15-20.

${ }^{107}$ Gray, Changing Colours, 129-35.

${ }^{108}$ Rutherford and Mirams, A Hell of a Way to Make a Living, 226-9.

${ }^{109}$ For example, Graham Mourie observed "of the highpoints along the way, no words can ever fully relate the heart-stopping, skin-tingling emotional impact a New Zealand rugby player feels the first time he hears he has been selected to play for his national side. Named in an All Black team. The goal of a lifetime" (Mourie and Palenski, Graham Mourie, Captain, 18).

${ }^{110}$ Crowe, Out on a Limb, back cover. On page 253 there is a virtually identical quote but "satisfies" is used instead of "fulfils."

${ }^{111}$ McCaw and McGee, The Open Side, 13-14.

${ }^{112}$ Max Rashbrooke, "Inequality and New Zealand," in Inequality: A New Zealand Crisis, ed. M. Rashbrooke (Wellington: Bridget Williams Books, 2013), 20-34. 